The Ether Extract of the Resin.-Upon concentrating the ethereal solution a quantity $(0.4 \mathrm{~g}$.) of material separated which gave the color tests characteristic for phytosterolins. It was purified by recrystallization from dilute pyridine and melted and decomposed at $280-290^{\circ}$.

$$
\text { Calc. for } \mathrm{C}_{33} \mathrm{H}_{56} \mathrm{O}_{6} \text { : C, } 72.3 ; \mathrm{H}, \text { I0.2 ; found: } \mathrm{C}, 72.4 ; \mathrm{H} \text {, I0.3. }
$$

The phytosterol glucoside was converted into an acetate which melted at $163-164^{\circ}$.

The ethereal solution from which this compound had separated was extracted with solutions of ammonium carbonate, sodium carbonate, and potassium hydroxide. The last named solution dissolved most of the material, but the further examination of both the potassium hydroxide solution and of the ether failed to yield any crystalline substances.

The Chloroform Ethyl Acetate, and Alcoholic Extracts of the Resin, were examined in an exhaustive manner but nothing could be isolated.

Kalamazoo, Mich.

[FROM THE DEPARTMENT OF ANIMAL HUSBANDRY OF THE UNIVERSITY OF ILLINOIS.]

\title{
THE QUANTITATIVE DETERMINATION OF THE AMINO ACIDS OF FEEDING-STUFFS BY THE VAN SLYKE METHOD.
}

By H. S. Grindley, W. E. Joseph and M. E. Slater.

Received April 27, 1915.

Studies relating to the amino-acid content of isolated proteins are of fundamental importance in revealing the character of the chemical processes involved in nutrition and in determining the relative nutritive value of the different proteins. The qualitative and the quantitative amino-acid content of most, if not all, of the forty or fifty natural proteins that have been isolated has been determined by such methods as are now available for such work. However, the quantitative amino-acid content of the mixed proteins of our feeding-stuffs is still entirely unknown. It is desirable, if possible, to determine the amino-acid values of feedingstuffs, since practical animal husbandry men must always deal with certain mixtures of proteins and protein derivatives as they are found in the naturally occurring feeds.

It is at present impossible to calculate the amino-acid content of feedingstuffs from the amino-acid content of the isolated proteins for two reasons: first, all of the proteins of any one of the common feeding-stuffs, except milk, have not as yet been isolated in a pure state; and second, there are as yet no methods available for the quantitative separation and determination of the proteins of feeding-stuffs, although some of the main proteins of a number of the feeding-stuffs have been qualitatively separated.

As T. B. Osborne has clearly pointed out, it is quite important for us to know, finally, if possible, the proportion of each type of protein con- 
tained in feeding-stuffs, yet, this is probably not so essential as a knowledge of the amino-acid content since the nutritive values of the mixed proteins of feeding-stuffs are ultimately determined by their amino-acid content and not by the proportion of the various proteins which they contain. If the amino acids can be determined without first isolating and purifying the proteins of the feeding-stuffs, the desired information can be obtained much more readily.

With the object of determining quantitatively the amino acids of feeding-stuffs we undertook to apply the Van Slyke ${ }^{1}$ method which he and other investigators have so successfully used in the determination. of the chemical groups characteristic of the different amino acids of proteins. In doing this work we have followed in considerable detail the Van Slyke method, with the exception that the quantities of the feedingstuff taken for the hydrolysis have necessarily been larger than the amounts of the protein material used by Van Slyke.

The results so far obtained are given in condensed form in Tables I and II. The duplicate or triplicate results reported for the same feedingstuff were obtained from the hydrolysis of two or three different portions of the same sample of cottonseed meal, tankage and alfalfa hay.

The results of the determinations given below indicate that the Van Slyke method for the determination of the chemical groups characteristic of the amino acids can be applied directly to the quantitative determination of amino acids of feeding-stuffs with at least a fair degree of accuracy.

Table I.-The Quantitative Determination of the Amino Acids of FeedingSTUFFS.

Results expressed in per cent. of the total nitrogen of the feeding-stuff.

\begin{tabular}{|c|c|c|c|c|c|c|c|c|c|}
\hline Feeding-stuffs. & $\begin{array}{l}\text { Am- } \\
\text { monia } \\
\text { N. }\end{array}$ & $\begin{array}{l}\text { Mel- } \\
\text { anine } \\
\text { N. }\end{array}$ & $\begin{array}{c}\text { Argin- } \\
\text { ipe } \\
\mathrm{N}\end{array}$ & $\begin{array}{l}\text { Cys- } \\
\text { tine } \\
\text { N. }\end{array}$ & $\begin{array}{l}\text { Histi- } \\
\text { dine } \\
\text { N. }\end{array}$ & $\begin{array}{l}\text { Iy- } \\
\text { sine } \\
\text { N. }\end{array}$ & $\begin{array}{c}\text { Amino } N \\
\text { in filtrate } \\
\text { from } \\
\text { bases. }\end{array}$ & $\begin{array}{c}\text { amino } \\
\text { in filtra } \\
\text { fromt } \\
\text { bases. }\end{array}$ & $\begin{array}{l}\text { e by } \\
\text { summa- } \\
\text { tion. }\end{array}$ \\
\hline \multirow{2}{*}{ Cottonseed meal. } & 10.46 & 7.65 & 19.33 & 0.62 & $5 \cdot 28$ & $5.8 \mathrm{I}$ & $42.6 \mathrm{I}$ & $5 \cdot 74$ & $97 \cdot 50$ \\
\hline & 10.30 & $7 \cdot 78$ & 19.49 & 0.65 & 4.90 & 4.33 & 42.04 & $5 \cdot 30$ & 94.79 \\
\hline " & 10.59 & 7.91 & 19.74 & 0.67 & 6.23 & $4.2 I$ & 43.80 & 5.26 & $98.4 \mathrm{I}$ \\
\hline Average. & 10.45 & $7 \cdot 7^{8}$ & 19.52 & 0.65 & 5.47 & $4 \cdot 78$ & 42.82 & 5.43 & 96.90 \\
\hline \multirow{3}{*}{\begin{tabular}{cc}
\multicolumn{2}{c}{ Tankage. } \\
" & \\
&
\end{tabular}} & 6.52 & 4.40 & 14.38 & $\mathrm{I}, 27$ & 5.15 & $7 \cdot 52$ & 52.36 & 7.27 & 98.87 \\
\hline & 6.56 & $4 \cdot 50$ & 14.18 & I. 24 & 4.76 & 7.64 & 52.57 & 7.17 & 98.6 \\
\hline & 6.66 & $4 \cdot 30$ & 13.88 & 1.32 & $4.9 \mathrm{r}$ & 7.28 & 52.24 & $7 \cdot 38$ & 97.97 \\
\hline Average. & 8 & $4 \cdot 40$ & 14.15 & I. 28 & 4.97 & $7 \cdot 4^{8}$ & 52.39 & 7.27 & . \\
\hline \multirow{2}{*}{$\underset{\text { Alfalfa hay. }}{\text { ". }}$} & 8.46 & 54 & 7 & 0.79 & $7 \cdot 39$ & 4.08 & 43.88 & IO. I4 & 98.0 \\
\hline & 8.42 & 16.03 & 7.64 & 0.97 & $7 \cdot 49$ & 4.12 & $44 \cdot 15$ & 9.43 & 98.15 \\
\hline Average......... & & 79 & 7.68 & 0.88 & $7 \cdot 44$ & $4 \cdot 10$ & 44.02 & 9.79 & 98. \\
\hline
\end{tabular}

${ }^{1}$ D. D. Van Slyke, J. Biol. Chem., 9, I85 (I9I1); I2, 275 (I912); I6, I2 I (I9I3-I4). 
Tabie II.-The Quantitative Determination of the Amino Acids of FegdingSTUFFs.

Results expressed in per cent. of the feeding-stuff.

\begin{tabular}{|c|c|c|c|c|c|c|c|c|c|}
\hline Feeding-s & $\begin{array}{l}\text { Am- } \\
\text { monia } \\
\text { N. }\end{array}$ & $\begin{array}{l}\text { Mel- } \\
\text { anine } \\
\text { N. }\end{array}$ & ine & $\begin{array}{l}\text { tine } \\
\text { N. }\end{array}$ & dine & $\begin{array}{l}\text { Ly- } \\
\text { sine } \\
\text { N. }\end{array}$ & $\begin{array}{c}\text { Amino } N \\
\text { in filtrate } \\
\text { from } \\
\text { bases. }\end{array}$ & $\begin{array}{c}\text { Non- } \\
\text { amino } N \\
\text { in filtrat } \\
\text { from } \\
\text { bases. }\end{array}$ & $\begin{array}{l}\text { Total } \\
\text { by } \\
\text { summa- } \\
\text { tion. }\end{array}$ \\
\hline $\begin{array}{c}\text { ottonseed meal } \\
" \text { " }\end{array}$ & $\begin{array}{l}0.702 \\
0.692 \\
0.711\end{array}$ & $\begin{array}{l}.514 \\
.522 \\
.531\end{array}$ & $\begin{array}{l}298 \\
309 \\
326\end{array}$ & $\begin{array}{l}0.04 \mathrm{I} \\
0.044 \\
0.045\end{array}$ & $\begin{array}{l}.355 \\
.329 \\
.418\end{array}$ & $\begin{array}{l}.390 \\
.291 \\
.283\end{array}$ & $\begin{array}{l}.862 \\
.824 \\
.94 I\end{array}$ & & $\begin{array}{l}6.547 \\
6.367 \\
6.608\end{array}$ \\
\hline Ave & 0.70 & $5^{2}$ & II & 3 & 7 & 21 & 36 & 0.365. & .5 \\
\hline $\begin{array}{c}\text { nkage. . . . } \\
" \quad \ldots \ldots \\
" \quad \ldots \ldots\end{array}$ & $\begin{array}{l}0.653 \\
0.657 \\
0.667\end{array}$ & 0.4 & 90 & $\begin{array}{l}124 \\
.132\end{array}$ & $\begin{array}{l}.477 \\
.492\end{array}$ & $\begin{array}{l}0.765 \\
0.729\end{array}$ & $\begin{array}{l}.238 \\
.264 \\
.213\end{array}$ & $\begin{array}{l}0.729 \\
0.718 \\
0.739\end{array}$ & $\begin{array}{l}9.896 \\
9.876 \\
9.782\end{array}$ \\
\hline Average..... & & & & & & & 8 & 29 & 9.851 \\
\hline $\begin{array}{c}\text { Ifalfa hay } \ldots . \\
\text { " } \\
\ldots \ldots\end{array}$ & $\begin{array}{l}0.221 \\
0.222\end{array}$ & $\begin{array}{l}0.408 \\
0.421\end{array}$ & $\begin{array}{l}0.203 \\
0.201\end{array}$ & $\begin{array}{l}0.02 \mathrm{I} \\
0.023\end{array}$ & $\begin{array}{l}0.194 \\
0.197\end{array}$ & $\begin{array}{l}0.107 \\
0.108\end{array}$ & $\begin{array}{l}\text { I. } 160 \\
\text { I. } 153\end{array}$ & $\begin{array}{l}0.248 \\
0.266\end{array}$ & $\begin{array}{l}2.553 \\
2.593\end{array}$ \\
\hline & & & & & & 08 & & & \\
\hline
\end{tabular}

At present we are unable to explain the consistently low percentages of the nitrogen of feeding-stuffs recovered as compared with the results obtained by Van Slyke for isolated proteins. This question is now being further studied in detail. A study is also being made of the free amide and the free amino acids of feeding-stuffs, with the object of determining to what extent, if any, the so-called nonprotein nitrogenous substances affect the quantitative determination of the amino acids of feeding-stuffs by the Van Slyke method.

It is evident from the results given in the above tables that there are marked differences in the amino-acid content of the three feeding-stuffs here reported. Hence, it is logical to suppose that the feeds would have a widely different nutritive value, particularly as supplements to such feeds as corn.

The quantitative determination of the amino acids of feeding-stuffs together with the aid of the rapidly increasing evidence on the nutritive functions of the amino acids will make it possible to extend our present knowledge of feeding-stuffs along the following lines:

First, the results will make it possible to calculate balanced rations from the standpoint of their amino-acid content that will be most efficient for the maintenance, the growth, and the fattening of farm animals.

Second, the results will be helpful in the interpretation of the results of past and future feeding experiments.

Third, the results should lead to a method of applying the recent and the fast accumulating results, as to the nutritive value of the amino acids, to the economic and nutritive valuation of the common feeding-stuffs. 
Fourth, the results will make it possible to plan and to make feeding experiments with farm animals with the natural mixtures of proteins as they occur in common feeding-stuffs, that will aid in the determination of the relative efficiency of the proteins of different feeding-stuffs for the maintenance, the growth, and the fattening of farm animals.

The determination of the amino acids of feeding-stuffs will be continued by this department. The results for a number of other feedingstuffs will be published in the near future. The quantitative determination of the amino acids of the roughages, such as the hays, corn fodder, corn silage, the grasses, the straws, and the roots and tubers will be especially valuable and interesting since as yet we have no knowledge of the nature of the proteins of these feeding-stuffs.

A study of methods for the separation and the quantitative estimation of the amino acids included in the groups represented by the amino nitrogen and the nonamino nitrogen in the filtrate from the bases obtained in the Van Slyke method has also been undertaken in this connection.

URBANA, ILL.

\section{NEW BOOKS.}

Elementary Chemical Microscopy. By Émile Monnin Chamot, Professor of Sanitary Chemistry and Toxicology, Cornell University. xiii +410 pp.; 130 figs. New York: John Wiley \& Sons, Inc. Price, $\$ 3.00$ net.

Notwithstanding the ever-increasing demands on the analytical chemist, the system of instruction in many American institutions has hardly changed since the days of Bunsen and Fresenius. Microscopic methods have been quite generally neglected. Most analysts approach the stage of the microscope with the fright of an amateur performer which is in striking contrast to the confident enthusiasm of Professor Chamot's students.

Since, at best, the laboratory work in analytical chemistry in the usual college course is only a start on the right road the student who has thorough grounding in several lines of attack is at a great advantage. With this equipment he can be left to schoolmaster Experience for the rest of his training.

Professor Chamot in his book has generously extended to students outside of his university and to those in practical work the advantages hitherto enjoyed only by his students. If the chemist is not called on to use the book in his college work he will at least find it useful in after-life.

The term "Chemical Microscopy" as used in the title is particularly fortunate and is much to be preferred to "Micro-chemistry" which suggests that the phenomena observed under the microscope are different from those seen with the naked eye.

Chapters I to XIII inclusive are devoted to the microscope, microscopic 